\title{
ACTIVITY-BASED COSTING DIFFUSION, STRATEGY AND ORGANIZATIONAL PERFORMANCE: EVIDENCE FROM IRAN
}

\author{
Seyed Mahmoud Miryazdi and Ruzita Jusoh*
}

\begin{abstract}
While management accounting literature has shown substantial evidence on $\mathrm{ABC}$ adoption and implementation within the Western context, this study attempted to provide some insight into the $\mathrm{ABC}$ diffusion stages within the Iranian context. Using a revised four-stage model in measuring activity-based costing $(\mathrm{ABC})$ diffusion, this study examines the performance consequence of $\mathrm{ABC}$ diffusion together with its relationship with Miles and Snow (1978) strategic types. From purposeful sampling of manufacturing companies listed in the Tehran Stock Exchange, a total of 400 survey questionnaires sent to these companies where 300 usable completed questionnaires were returned and analysed. Hypotheses were tested using ordinal logistic regression and ANOVA analyses. The results showed that firms at higher ABC diffusion stages have better levels of organizational performance than firms at the lower ABC diffusion stages. In addition, the analyzer strategy was a significant factor in determining a firm's decision to go to higher ABC diffusion stages.
\end{abstract}

Keywords: Activity-Based Costing; Innovation; Strategy; Performance JEL classification: M41

\section{Introduction}

Cost accounting measures the cost of products or services for management accounting purposes in the financial reporting process as well as sell or buy decisions, transfer pricing, value inventory, cost control, and performance determination (Johnson and Kaplan,1987). Traditional costing systems which designed for manufacturing environments typically have direct costs which are larger in percentages than the total costs. However, in the past three decades, overhead cost has increased impressively and became the dominant cost component of many products. The published $\mathrm{ABC}$ literature shows that overheads are becoming a progressively larger component of product cost (e.g. Ahmadzadeh et al., 2011; Drury and Tayles, 2005). During the same time period, many scholars criticise that traditional cost accounting does not provide

\footnotetext{
*Corresponding author: Ruzita Jusoh is an Associate Professor at the Department of Accounting, Faculty of Business and Accountancy, University of Malaya, 50603 Kuala Lumpur, Malaysia. Email: geee@um.edu.my.

Seyed Mahmoud Miryazdi is a Lecturer at the Faculty of Management and Social Sciences, Islamic Azad University, North Tehran Branch, Tehran, Iran. Email: mahyazdi@yahoo.com
} 
an accurate model for the allocation of overheads. Thus, it fails to produce accurate information for improving management decisions (e.g. Krumwiede, 1998; Cooper and Kaplan, 1991). To overcome the weakness of traditional cost accounting, ABC was introduced during the 1980s and 1990s. According to Askarany et al. (2007), ABC is one of the main cost and management accounting innovation systems in the $20^{\text {th }}$ Century. Krumwiede (1998) believes that changes introduced by $\mathrm{ABC}$ provide a transparent process cost description and reveal profitability based on objectives.

Previous studies provide a general conclusion that there is a positive relationship between $\mathrm{ABC}$ diffusion and organizational performance (e.g. Askarany and Yazdifar, 2012; Banker et al., 2008; Abernethy and Bouwens, 2005; Hughes, 2005; Kennedy and Affleck-Graves, 2001; Mia and Clarke, 1999). Cooper et al. (1992) argue that the goal of ABC is to increase profits, and not to obtain more accurate costs. ABC researchers discovered many benefits of $\mathrm{ABC}$ diffusion. These include better measurements of cost, product costing and performance (Khalid, 2005); better understanding of cost reduction opportunities, managerial decision improvement, and cost control (Moll, 2005); and the improvement in business cost-efficiency (Innes and Mitchell, 1995). Despite the stated benefits, limited knowledge is available on the performance consequence of $\mathrm{ABC}$, particularly in the Iranian context. Therefore, it is of interest to explore the implementation of $\mathrm{ABC}$ among the Iranian manufacturing companies and to discover its diffusion stages on organizational performance.

Moreover, management accounting literature highlights that firms place more emphasis on particular accounting techniques or information depending on their adopted strategy. In addition, several researchers found evidence supporting those particular types of innovation belonging to a specific business strategy (e.g. Jusoh et al., 2006; Bhimani et al., 2005). However, in the Iranian context, empirical evidence on how a particular strategy deployment influences $\mathrm{ABC}$ diffusion process remains limited. Therefore, the relevance and importance of business strategy to $\mathrm{ABC}$ implementation lend strong support for this study to examine the relationship between business strategy and $\mathrm{ABC}$ diffusion stages. More specifically, this paper highlights (1) how prospector and defender strategic types relate to $A B C$ diffusion stages, and (2) how organizational performance differs at different $\mathrm{ABC}$ diffusion stages. 


\section{Literature Review and Hypothesis Development}

\subsection{ABC diffusion}

Rogers (2003, p. 5) defines diffusion as "the process which an innovation communicated through certain channels over the time among the members of social system". He highlighted four elements of diffusion process which include: "1) an innovation, 2) communicated through certain channels, 3) over the time, and 4) among the members of social system".

Meanwhile, Bjørnenak (1997, p. 4) defines "an innovation" as a successful introduction of new ideas among the social system. Likewise, Damanpour (1987, p. 676) defines innovation as an idea, a system which is new to the firms at the time of adopting it. In line with the innovation definition, several researchers considered $\mathrm{ABC}$ as an innovation in cost accounting systems (e.g. Al-Omiri and Drury, 2007; Brown et al., 2004; Gosselin, 1997; Anderson, 1995; Innes and Mitchell, 1995).

Second element of diffusion process is "communication through certain channels". Rogers (2003, p. 18) believes that "communication is a process" of sharing information for understanding of innovation and it causes potential adopters become responsive of the innovation. For innovation diffusion to occur successfully in the organizations, their employees must be aware of the innovation. To create employee awareness of $\mathrm{ABC}$ diffusion, communication can be done through various channels such as workshops, trainings, meetings or conferences, magazines, and membership journals (Bjørnenak, 1997). Several researchers believed that if employees do not recognize why or how ABC works they cannot complete the diffusion process (e.g. Shields and McEwen, 1996).

Time is the third element of diffusion process which measures temporal range in completing the task. Time refers to number of years since $\mathrm{ABC}$ was adopted (Krumwiede, 1998). He finds that realization of the advantages of ABC occurs when its diffusion completed and this process normally takes time. Many researchers (see Table 1) suggest the stages models for describing $A B C$ diffusion because they can carefully capture the variations due to timing issues. In line with these researchers, the current study considers diffusion as stage models and conceptualizes diffusion as a series of stages that unfold over time in which later stages cannot be undertaken unless earlier stages completed. Table 1 summarizes various ABC Diffusion Stage Models adopted by previous ABC studies.

The last Rogers's (2003) diffusion element is "members of social system". Rogers (2003) explains that these members may be individual, informal groups, sub-systems, and organizations. The current study considers manufacturing companies as members of social system. 
Table 1: Diffusion Stages Models

\begin{tabular}{|c|c|}
\hline Research & Stages of Diffusion \\
\hline Ahmadzadeh et & 1) Reject, 2) Non-Consider, 3) Consider4) Under Implementation, 5) \\
\hline al. (2011) & Implementation compete \\
\hline $\begin{array}{l}\text { Cohen et al. } \\
(2005)\end{array}$ & 1) $\mathrm{ABC}$ unawares, 2) $\mathrm{ABC}$ deniers, 3) $\mathrm{ABC}$ supporters, 4) $\mathrm{ABC}$ adopters \\
\hline Kiani \& & 1) I am not sure, 2) Never seriously considered, 2) Considering, \\
\hline $\begin{array}{l}\text { Sangeladji } \\
(2003)\end{array}$ & $\begin{array}{l}\text { 3) Considered, but rejected it, 4) Considering using, but have not made a } \\
\text { decision, 5) Attempted, but rejected it, 6) Planning to implement in the } \\
\text { future, 7) Recently have started to implement, but have not fully } \\
\text { implemented it yet, } \\
\text { 8) ABC is a well-established in our company. }\end{array}$ \\
\hline Clarke \& & 1) Reject $\mathrm{ABC}$ system 2) Have not considered $\mathrm{ABC}$ \\
\hline Mullins (2001) & $\begin{array}{l}\text { 3) Not using } A B C \text { but may consider it in future } \\
\text { 4) Assessing } A B C, 5 \text { ) Adopted } A B C\end{array}$ \\
\hline Krumwiede & 1) Initiation, 2) Adoption, 3) Analysis \\
\hline Roth (1997) & 4) Action, 5) Activity Based Management. \\
\hline Clarke et al. & 1) No consideration of $A B C, 2)$ Rejected $A B C$ \\
\hline (1999) & 3) Assessing $\mathrm{ABC}$, 4) Implemented $\mathrm{ABC}$ \\
\hline Krumwiede & 1) Not considered, 2) Considering, 3) Considered, then rejected, \\
\hline (1998) & $\begin{array}{l}\text { 4) Evaluated and approved for analysis, 5) Analysis, 6) Gaining acceptance 7) } \\
\text { Implemented then abandoned, 8) A acceptance, 9) Routine system, 10) Integrated } \\
\text { system }\end{array}$ \\
\hline $\begin{array}{l}\text { Anderson } \\
(1995)\end{array}$ & 1) Initiation, 2) Adoption, 3) Adaptation, 4) Acceptance \\
\hline Innes \& & 1) No consideration of $\mathrm{ABC}, 2)$ Rejected $\mathrm{ABC}$ after assessment \\
\hline Mitchell (1995) & 3) Currently considering $\mathrm{ABC}, 4$ ) Currently using $\mathrm{ABC}$ \\
\hline
\end{tabular}

As shown in Table 1, stage models are considered useful from both research and practice perspectives. In most $\mathrm{ABC}$ empirical studies, $\mathrm{ABC}$ is looked at as a multiple diffusion stage mode (e.g. Al-Omir and Drury, 2007; Maelah and Ibrahim, 2006; Brown et al., 2004; Innes et al., 2000; Krumwiede and Roth, 1999; Krumwiede, 1998b; Anderson, 1995; Innes and Mitchell, 1995). Stage models may better show the degree of usage of $\mathrm{ABC}$ systems by highlighting the stage of an occupant. Brown et al. (2004) explained that ABC diffusion relates to the process of carrying out $\mathrm{ABC}$ adoption decisions and should be considered as stages. Bjørnenak (1997) described that the model of ABC diffusion is at the shortening stage of the process. He believes that the stage models are based on an elaborate set of assumptions and that the stages mark the diffusion mechanism. Innes et al. (2000) described that the stage as the level of use has been able to identify how an organization promotes $\mathrm{ABC}$ usage.

Wolfe (1994) found that the direction of the influence of some factors on innovation is dependent upon the stage being considered. Cooper and Zmud (1990) was one of the empirical studies that investigated whether certain factors affect diffusion stages differently. They applied a six-stage model developed by Kwon and Zmud (1987) to study the diffusion of material requirements planning (MRP) systems. They used adoption and infusion stages for analysis. They 
found that some factors are significant in explaining MRP Adoption, but that they are not significant in explaining MRP Infusion.

Anderson (1995) developed ABC diffusion research. She suggested a theory that in the association with diffusion stages of $\mathrm{ABC}$, many factors vary by stage. These variations concern the characteristics of direction and/or level of importance in the relationships. She found evidence supporting this theory. In her study, organizational factors, such as top management support and training, affect the various stages in different ways. Likewise, environmental factors, such as competition, vary in their impact among the diffusion stages. Some ABC researchers who tested this theory with different stage models and different factors also found evidence supporting this theory (e.g. Krumwiede, 1998; Gosselin, 1997; Brown et al., 2004).

\subsection{Strategy and ABC Diffusion}

Many researchers consider business strategy as an environmental factor (e.g. Brown et al., 2004; Gosselin, 1997). Galbreath (2009, page 110) proposed six dimensions of business strategy which include: 1) Mission: What is a firm trying to accomplish in the long-term?, 2) Strategic issue: What internal and external issue effect on the firm's capability to achieve its mission?, 3) Market: Which market should a firm compete in?, 4) Customer needs: What product/services are needed to offer customers in chosen market?, 5) Resources: What resources (facilities, assess, skills, tools, finance, and relationships) are necessary in order to compete?, 6) Competitive advantage: How can a firm achieve better than competitors? Further, Croteau and Bergeron (2001) argued that business strategy is an action that managers take for achieving organization's goals with respect to the internal structure/processes, and external environment.

They are two schools of strategy typologies widely used in most business research. The typologies were developed by Miles and Snow (1978) and Porter (1987). Miles and Snow (1978) suggest four types of strategy. These are prospector, defender, analyzer, and reactor strategies. later, Porter (1987) developed three generic strategies through which an organization can gain a sustainable competitive advantage. Porter's (1987) strategies are cost leadership, product differentiation, and focus. Since Gosselin (1997) believes that Miles and Snow's typology is more suitable to examine the concern of an innovation in management accounting systems such as $\mathrm{ABC}$, this study adopted the same strategy typology. 
Based on Miles and Snow's (1978) typology, prospectors have enthusiasm in searching market opportunities. They invest large financial resources for research and development and teamwork improvement Defenders strategize the absolutely opposite to prospectors. They have low product diversity and high production volume. Defenders participate aggressively in quality, customer service, and price. Analyzers share characteristics of both prospectors and defenders and stand in between these two groups. The fourth strategy is reactors, which does not follow an apprised strategy (Miles and Snow 1978). The principle of the Miles and Snow typology is that defender, analyzer and prospector strategies, if appropriately implemented, can lead to effective performance (Gosselin, 1997).

Several studies claimed that there is a link between ABC diffusion and business strategy (e.g. Gosselin, 1997; Al-Omiri and Drury, 2007). However, such claim is still inconclusive with respect to strategic types. For example, AlOmiri and Drury (2007) and Bhimani et al. (2005) compared two types of Miles and Snow typologies and found evidence that $\mathrm{ABC}$ diffusion is higher for defenders than for prospectors. Furthermore, Gosselin (1997) compared all types of Miles and Snow typologies and found evidence indicating that prospectors are more likely to diffuse $\mathrm{ABC}$ than analyzers and defenders. Meanwhile, Alcouffe (2002) found that the proportion of firms pursuing prospector and analyzer strategies among the French companies adopting $\mathrm{ABC}$ is greater than those found among businesses not adopting the method. Moreover, a study by Collins et al. (1997) could lend some support for strategy-ABC relationship when they conducted a survey to identify the effect of business strategy on adoption of management accounting systems (MAS) in terms of budgetary adoption. The only significant relationship that they found is between prospector and MAS adoption. So far, none of Iranian studies mentioned any particular types of innovation belonging to a specific business strategy. Thus, the foregoing arguments lead to the following hypothesis:

H1: Prospectors are more likely to be at higher stages of $A B C$ diffusion than defenders and analyzers.

\subsection{ABC diffusion and Organizational Performance}

Damanpour (1987) believes that managers involved in the issue of improving their organizational performance by adopting innovations. $\mathrm{ABC}$ analysis, according to Cooper and Kaplan (1991), allows managers to recognize the sources and their cost drivers and enables them to reduce the demands on their organizational resources. Further, there are evidences indicating a positive relationship between $\mathrm{ABC}$ diffusion and organizational performance (e.g. 
Askarany and Yazdifar, 2012; Banker et al., 2008; Abernethy and Bouwens, 2005; Hughes, 2005; Kennedy and Affleck-Graves, 2001; Mia and Clarke, 1999).

Banker et al. (2008) revealed that $\mathrm{ABC}$ has a positive impact on plant performance, while Cagwin and Bouwman (2002) found evidence that $\mathrm{ABC}$ diffusion relates positively to firms' return on investment (ROI). Gering (1999) argued that firms with diffused $\mathrm{ABC}$ may improve performance by focusing on which customer or product that is profitable. In addition, Innes and Mitchell (1995) asserted that the key areas of ABC advantages are improving business cost-efficiency by reducing costs as well as developing product costing to improve product profitability. However, the existing literature shows that despite the claimed benefits of using activity-based costing; the level of diffusion of this system is still lower than the traditional one. Gosselin (1997) describes this fact as the "ABC paradox". He asserted that it seems a gap exists between the great interest of management accountants in using $\mathrm{ABC}$ and the number of organizations that have actually adopted and diffused it. Rios-Manriquez et al. (2014) found that the ABC users were only 7.22\% in Mexican SMEs. Among the reasons why Mexican SMEs did not use the $\mathrm{ABC}$ include: high costs involved in implementing $\mathrm{ABC}$; problems in adapting to the firm's information system: and accounting problems with the general accounting system. In order to solve the $\mathrm{ABC}$ paradox and provide additional empirical evidence on performance consequences of $\mathrm{ABC}$ within Iranian context, the following hypothesis was formulated:

H2: Firms with higher ABC diffusion stages have higher levels of organizational performance than firms with lower $A B C$ diffusion stages

\section{Research Methodology}

\subsection{Research Design and Sample}

The study employed a mail survey to collect data. The Tehran Stock Exchange (TSE) served as the sampling frame of the study with a population of 451 companies. As the study focuses only on manufacturing firms, 51 nonmanufacturing companies were excluded from the sampling frame. Researchers mailed 400 questionnaires to the chief financial officers (CFO) of manufacturing companies selected. CFOs selected are expected to understand the cost accounting systems and are key persons responsible for the $\mathrm{ABC}$ implementation.

Consistent with previous studies, researchers carried out two rounds of mailings. During the first round, 400 questionnaires were sent to selected companies for the attention of the CFO. Researchers mailed follow up reminders 
a month later which could improve the response rate. A total of 300 questionnaires were returned, of which 188 are usable, yielding a response rate of $47 \%$.

\subsection{Variable Measurement}

Strategy: The present study examined the degree to which firms emphasize each of the business strategy types proposed by Miles and Snow (1978). This typology identifies four strategic types. These are prospectors, defenders, analyzers, and reactors. The survey questions with regard to business strategy were adopted from Jusoh and Parnell (2008). There were twelve questions and each question consists of four item statements which measure each type of business strategy (48 items in total) as depicted in Appendix 1. The respondents were asked to indicate agreement or disagreement with each statement concerning their organization by using a five-point Likert scale including: $1=$ strongly disagree, $2=$ disagree, $3=$ somewhat agree, $4=$ agree, $5=$ strongly agree. Business strategy was operated by taking the mean score across the twelve items in four strategic types. Then, for each firm the degree of the mean value which was classified into four strategic types was compared. The highest value indicated which firm emphasizes a given strategy. As a result, the firm strategy was treated as a nominal variable.

$A B C$ Diffusion: ABC diffusion stages were assessed using the measurement adopted from Krumwiede and Suessmair (2005) which was developed based on Krumwiede's (1998) and Krumwiede and Roth (1997) studies. The respondents were asked to mark the description that best describes the current situation of their company according to the seven diffusion stages. The measurement uses seven diffusion stages: $\mathrm{ABC}$ not considered, $\mathrm{ABC}$ considered then rejected, $\mathrm{ABC}$ considering, $\mathrm{ABC}$ implemented then abandoned, $\mathrm{ABC}$ used occasionally, $\mathrm{ABC}$ used frequently, and $\mathrm{ABC}$ used extensively. The level of usage is measured by ordinal scale (see Appendix 2). Organizational Performance: A multidimensional performance measurement was used in measuring the level of organizational performance. The instrument was adopted from Moll (2005) who used a self-rating scale developed by Govindarajan and Gupta (1985). Two questions were used to measure the level of organizational performance. The first question measures the value for the performance importance of 16 performance dimensions where the respondents were asked to rate the importance from "Not Important" (1) to "Extremely Important" (5) for each of the 16 performance aspects (see Appendix 3). The second question measures the value for the performance achievement of the same 16 performance dimensions where respondents were asked to rate their perceptions of company performance 
achievement relative to that of their competitors using a five-point Likert-type scale ranging from "Strongly below the Average" (1) to "Strongly above the Average" (5). A weighted average performance index was calculated for each firm by multiplying each performance importance item by its relevant performance achievement item. This lets for the establishment of a performance index that acknowledges the differing performance purposes of firms. This approach is similar to that used by Govindarajan and Gupta (1985) and Abernethy and Bouwens (2005).

\section{Results}

Table 2 shows the number of responding firms and their respective industries. The majority of the firms were in the ore and mining products $(10.6 \%)$, followed by chemicals and petroleum products $(9.6 \%)$, and non-sugar products, metals products, and textiles products $(8.5 \%)$.

Table 2: Sample Industries Group

\begin{tabular}{llcc}
\hline & Industries & Number & Percentage \\
\hline 1 & Electric Machinery \& Apparatus & 7 & 3.72 \\
2 & Wood, Publishing, and Printing Products & 9 & 4.79 \\
3 & Medical products & 13 & 6.91 \\
4 & Cement, Lime, and Gypsum Products & 11 & 5.85 \\
5 & Chemicals and Petroleum Products & 18 & 9.57 \\
6 & Non-sugar Products & 16 & 8.51 \\
7 & Metals Products & 16 & 8.51 \\
8 & Sugar Products & 9 & 4.79 \\
9 & Non-metallic Products & 9 & 4.79 \\
10 & Furniture, Computer Products & 11 & 5.85 \\
11 & Machinery Equipment Products & 11 & 5.85 \\
12 & Ores Mining Products & 20 & 10.64 \\
13 & Textiles Products & 16 & 8.51 \\
14 & Motor Vehicles and Auto Parts products & 15 & 7.98 \\
15 & Other Products & 7 & 3.72 \\
& Total & 188 & 100.00 \\
\hline
\end{tabular}

\subsection{Factor Analysis and Reliability}

A principal component analysis (PCA) with varimax rotation was performed for the 16 items of the performance index. Following factor loading results, five items (competitor monitoring, profile with the community, cost, customer monitoring, and employee safety) were deleted from the analysis for their low factor loading (less than 0.50) and cross- loadings. As shown in Table 3, two component factors were extracted, accounting for a total of $55.71 \%$ of the variance with eigenvalues exceeding 1.0. Factor 1 consists of six items (on time 
delivery, customer satisfaction, productivity of labour, time to process activities, product quality, and new product introduction) that explains $30.75 \%$ of the variance. This factor was named "non-financial performance". Factor 2 was named as "financial performance" and consists of five items (cash flow, cost reduction, return on investment, market share, and sales volume) explaining $24.96 \%$ of the variance.

Table 3: Results of the Principal Component Factor Analysis for Performance Measures

\begin{tabular}{lllll}
\hline Component & Items & $\begin{array}{l}\text { Factor } \\
\text { Loadings }\end{array}$ & Eigenvalue & $\begin{array}{l}\text { Percentage of } \\
\text { Variance } \\
\text { Explained }\end{array}$ \\
\hline 1 & & & 30.75 \\
& On time delivery & .776 & 3.38 & \\
& Customer satisfaction & .775 & & \\
& Productivity of labour & .770 & & \\
& Time to process activities & .748 & & \\
& Products quality & .640 & 2.96 & \\
& New product introduction & .589 & & \\
& Cash flow & .730 & & \\
& Cost reduction & .700 & & \\
& Return on investment & .692 & & \\
& Market share & .674 & & \\
& Sales volume & .670 & & \\
\hline
\end{tabular}

Table 4 presents Cronbach's alpha coefficients which indicate the reliability for multi-item variables in this study. All the Cronbach's alpha coefficients exceed 0.70 indicating good reliability as suggested by Sekaran et al. (2000).

Table 4: Reliability of the Multi-Items

\begin{tabular}{ll}
\hline Variables & Cronbach Alpha \\
\hline Business strategy-Prospector & 0.88 \\
Business strategy-Defender & 0.81 \\
Business strategy-Analyzer & 0.85 \\
Business strategy-Reactor & 0.80 \\
Performance-Financial & 0.78 \\
Performance-Non-financial & 0.85 \\
\hline
\end{tabular}

\subsection{Descriptive Statistics}

Table 5 contains the descriptive statistics for the variables. The majority of the firms adopt reactor strategy (32.5\%), followed by defender strategy $(27.1 \%)$, analyzer strategy $(21.3 \%)$ and prospector strategy (19.1\%). Initially, the current study proposed a seven-stage model for measuring $\mathrm{ABC}$ diffusion. However, the data revealed that there are no firms in three of the stages (Stage 2: Evaluated then rejected, Stage 4: Implemented then abandoned, and Stage 6: Used frequently). As the data only captured responding firms in four stages, a fourstage model was then used in the data analysis. This model represents: Stage 1- 
ABC Not considered $(n=112)$, followed by Stage 3-ABC Considering $(n=43)$, Stage 5-Used occasionally $(n=20)$, and Stage 7-Used extensively $(n=13)$. This model is considered a continuous and complete diffusion model which was also proposed earlier by other researchers (e.g. Innes et al., 2000; Clarke et al., 1999; Gosselin, 1997; Anderson, 1995). This four-stage model is sufficient to do further analyses on the relative importance of strategy variable and performance consequences at different stages of $\mathrm{ABC}$ diffusion.

Table 5: Descriptive Statistics

\begin{tabular}{llll}
\hline Business Strategy & Frequency & Percentage & Cumulative \% \\
\hline Analyzers & 40 & 21.28 & 21.28 \\
Defenders & 51 & 27.13 & 48.41 \\
Prospectors & 36 & 19.14 & 67.55 \\
Reactors & 61 & 32.45 & 100.00 \\
& & & \\
ABC Diffusion Stages & Frequency & Percentage & Cumulative \% \\
\hline Stage one-Not considered & 112 & 59.58 & 59.58 \\
Stage Two-Evaluated then rejected & 0 & 0.00 & 59.58 \\
Stage Three-Considering to ABC & 43 & 22.87 & 82.45 \\
Stage Four -Implemented then abandoned & 0 & 0.00 & 82.45 \\
Stage Five-Used occasionally & 20 & 10.64 & 93.09 \\
Stage Six -Used frequently & 0 & 0.00 & 93.09 \\
Stage Seven-Used extensively & 13 & 6.91 & 100.00 \\
\hline
\end{tabular}

A preliminary review of the cross-tabulation results helps explaining the relationships between $\mathrm{ABC}$ diffusion and business strategy (see Table 6). Most firms in Stage 5 and Stage 7 followed analyzer strategy. Based on these preliminary results, it seems that hypothesis 1 is not supported.

Table 6: Cross-tabulation Result of ABC Diffusion Stages and Strategy

\begin{tabular}{llllll}
\hline & \multicolumn{2}{l}{ ABC Diffusion Stage } & & & \\
& Stage 1 & Stage 3 & Stage 5 & Stage 7 & Total \\
\hline Strategy-Analyzer & 14 & 10 & 10 & 6 & 40 \\
Strategy-Defender & 31 & 15 & 3 & 2 & 51 \\
Strategy-Prospector & 27 & 2 & 4 & 3 & 36 \\
Strategy-Reactor & 40 & 16 & 3 & 2 & 61 \\
Total & 112 & 43 & 20 & 13 & 188 \\
\hline
\end{tabular}

\subsection{Ordinal Logistic Regression - Business Strategy and ABC Diffusion}

To test for $\mathrm{H} 1$ that states that prospector strategy is at higher stages of $\mathrm{ABC}$ diffusion, an ordinal logistic regression was performed. ABC diffusion stage is a dependent and ordinal variable with four stages (Stage 1, Stage 3, Stage 5 and Stage 7) while business strategy is an independent and nominal variable which includes four business strategy types: prospector, defender, analyzer, and reactor. In the analysis, prospector, defender, and analyzer strategies were 
considered as dummy variables while reactor strategy was considered as the reference group.

Referring to Table 7, the results show a model fit. The $-2 \log$ likelihood for the final model is equal to 50.47 and chi-square equals to 17.43 with p-value > 0.01. As shown in Table 7, the p-value for both Strategy-Defender and StrategyProspector are not significant ( $\mathrm{p}$-value > 0.10) indicating the absence of both strategies' effect on ABC diffusion stages when compared with StrategyReactors. On the other hand, Strategy-Analyzer is significant at $\mathrm{p}<0.01$, indicating that the Strategy-Analyzer influenced ABC diffusion stages more than Strategy-Reactors. The $b$ parameter shows positive effect $(+1.426)$ for StrategyAnalyzer indicating that the probability of accessing the higher ABC diffusion stages in firms which used Strategy-Analyzer is 1.426 times higher than firms with Strategy- Reactors. The result results show that firms with analyzer strategy are more motivated to be in higher $\mathrm{ABC}$ diffusion stages compared to other strategies. This result is contrary to expectation, thus, H1 is not supported.

Table 7: Ordinal Logistic Results: ABC Implementation Model

\begin{tabular}{lrrrrr}
\hline Predictor & Parameter Estimate & Std.Error & Wald Chi Square & df & p-value \\
\hline Strategy-Analyzer & 1.426 & 0.398 & 12.855 & 1 & 0.001 \\
Strategy-Defender & 0.189 & 0.388 & 0.238 & 1 & 0.626 \\
Strategy-Prospector & -0.229 & 0.453 & 0.254 & 1 & 0.614 \\
Test & & & Wald Chi Square & df & p-value \\
Overall model fitting evaluation & & & 17.43 & 3 & 0.01 \\
\hline Note: $-2 \log$ likelihood=50.474, Cox and Snell R2=0.098, Nagelkerke R2=0.100 & &
\end{tabular}

\subsection{ANOVA Test - ABC Diffusion and Organizational Performance}

To test $\mathrm{H} 2$, ANOVA tests were conducted. Table 8 presents the ANOVA results for the difference in financial performance among the $\mathrm{ABC}$ diffusion stages. The result provides evidence $(\mathrm{p}<.001)$ that the level of financial performance differs from the lower stage to the higher stages of ABC diffusion. To determine which specific stages differ significantly, Multiple Comparisons tests using the Tukey post-hoc method was applied. As shown in Table, 9, the Multiple Comparisons table shows that stages 7-1, stages 7-3 and stages 7-5 differences are significant. Further, as shown in Table 10, the mean values of firms' financial performance in higher $\mathrm{ABC}$ diffusion stages are higher than those in the lower stages. 
Table 8: ANOVA Result, ABC Diffusion and Financial Performance

\begin{tabular}{llrrrrr}
\hline $\begin{array}{l}\text { Financial } \\
\text { Performance }\end{array}$ & & $\begin{array}{r}\text { Sum of } \\
\text { Squares }\end{array}$ & df & $\begin{array}{r}\text { Mean } \\
\text { square }\end{array}$ & F & p-value \\
\cline { 2 - 7 } & Between Groups & 562.762 & 3 & 187.587 & 13.663 & .001 \\
& Within Groups & 2526.317 & 184 & 13.730 & & \\
& Total & 3089.079 & 187 & & & \\
\hline
\end{tabular}

Table 9: Multiple Comparisons, ABC Diffusion and Financial Performance (Post Hoc Tests)

\begin{tabular}{llrrrrr}
\hline $\begin{array}{l}\text { (I) ABC } \\
\text { Diffusion }\end{array}$ & $\begin{array}{l}\text { (J) ABC } \\
\text { Diffusion }\end{array}$ & $\begin{array}{r}\text { Mean } \\
\text { Difference } \\
(\mathbf{I}-J)\end{array}$ & $\begin{array}{c}\text { Std. } \\
\text { Error }\end{array}$ & & Sig. & \multicolumn{2}{c}{ 95\% Confidence Interval } \\
& & & & & $\begin{array}{c}\text { Lower } \\
\text { Bound }\end{array}$ & $\begin{array}{r}\text { Upper } \\
\text { Bound }\end{array}$ \\
\cline { 3 - 7 } 1 & 3 & -1.22662 & 0.66475 & 0.256 & -2.9501 & 0.4969 \\
& 5 & $-2.71964^{*}$ & 0.89949 & 0.015 & -5.0517 & -0.3876 \\
& 7 & $-6.47349^{*}$ & 1.0857 & 0 & -9.2883 & -3.6586 \\
3 & 1 & 1.22662 & 0.66475 & 0.256 & -0.4969 & 2.9501 \\
& 5 & -1.49302 & 1.0029 & 0.446 & -4.0932 & 1.1071 \\
& 7 & $-5.24687^{*}$ & 1.1728 & 0 & -8.2875 & -2.2062 \\
5 & 1 & $2.71964^{*}$ & 0.89949 & 0.015 & 0.3876 & 5.0517 \\
& 3 & 1.49302 & 1.0029 & 0.446 & -1.1071 & 4.0932 \\
& 7 & $-3.75385^{*}$ & 1.3201 & 0.025 & -7.1764 & -0.3313 \\
7 & 1 & $6.47349^{*}$ & 1.0857 & 0 & 3.6586 & 9.2883 \\
& 3 & $5.24687^{*}$ & 1.1728 & 0 & 2.2062 & 8.2875 \\
& 3 & $3.75385^{*}$ & 1.3201 & 0.025 & 0.3313 & 7.1764 \\
\hline
\end{tabular}

*. The mean difference is significant at the 0.05 level.

Table 10: Descriptive statistics, ABC Diffusion and Financial Performance

\begin{tabular}{lrrrr|}
\hline & Low & High & Mean & Standard deviation \\
\hline Stage one $(\mathrm{N}=112)$ & 2.40 & 20.20 & 11.08 & 3.742 \\
Stage three $(\mathrm{N}=43)$ & 2.40 & 21.20 & 12.30 & 3.693 \\
Stage five $(\mathrm{N}=20)$ & 8.40 & 20.40 & 13.80 & 3.785 \\
Stage seven $(\mathrm{N}=13)$ & 11.80 & 22.00 & 17.55 & 3.248 \\
\hline
\end{tabular}

Further, ANOVA results in Tables 11 show that the level of non-financial performance differs significantly from the lower stage to the higher stages of ABC diffusion. As shown in Table, 12, the Multiple Comparisons table shows that stages 7-1, stages 7-3, and stages 7-5 differences are significant. It further indicates that (see Table 13) the mean values of the firms' non-financial performance in higher $\mathrm{ABC}$ diffusion stages are higher than those in the lower stages.

Table 11: ANOVA Result, ABC Diffusion and Non-Financial Performance

\begin{tabular}{llrrrrr}
\hline $\begin{array}{l}\text { Non- } \\
\text { Financial } \\
\text { Performance }\end{array}$ & $\begin{array}{r}\text { Sum of } \\
\text { Squares }\end{array}$ & df & $\begin{array}{r}\text { Mean } \\
\text { square }\end{array}$ & F & $\begin{array}{r}\text { p- } \\
\text { value }\end{array}$ \\
\cline { 2 - 7 } & Between Groups & 457.29 & 3 & 152.430 & 10.032 & .001 \\
& Within Groups & 2795.63 & 184 & 15.194 & & \\
\hline & Total & 3252.92 & 187 & & & \\
\hline
\end{tabular}


Table 12: Multiple Comparisons, ABC Diffusion and Non- Financial

Performance (Post Hoc Tests)

\begin{tabular}{llrrrrr}
\hline $\begin{array}{l}\text { (I) ABC } \\
\text { Diffusion }\end{array}$ & $\begin{array}{l}\text { (J) ABC } \\
\text { Diffusion }\end{array}$ & $\begin{array}{r}\text { Mean } \\
\text { Difference } \\
\text { (I-J) }\end{array}$ & $\begin{array}{c}\text { Std. } \\
\text { Error }\end{array}$ & & Sig. & \multicolumn{2}{c}{95 Confidence Interval } \\
& & & & & Lower Bound & $\begin{array}{r}\text { Upper } \\
\text { Bound }\end{array}$ \\
\cline { 3 - 7 } 1 & & -0.163 & 0.69928 & 0.996 & -1.976 & 1.65 \\
& 3 & -0.66009 & 0.94622 & 0.898 & -3.1133 & 1.7932 \\
& 5 & $-6.21201 *$ & 1.1421 & 0 & -9.1731 & -3.2509 \\
3 & 7 & 0.163 & 0.69928 & 0.996 & -1.65 & 1.976 \\
& 1 & -0.49709 & 1.055 & 0.965 & -3.2323 & 2.2382 \\
& 5 & $-6.04902^{*}$ & 1.23373 & 0 & -9.2477 & -2.8504 \\
5 & 7 & 0.66009 & 0.94622 & 0.898 & -1.7932 & 3.1133 \\
& 1 & 0.49709 & 1.055 & 0.965 & -2.2382 & 3.2323 \\
& 3 & $-5.55192^{*}$ & 1.38868 & 0.001 & -9.1523 & -1.9516 \\
7 & 7 & $6.21201^{*}$ & 1.1421 & 0 & 3.2509 & 9.1731 \\
& 1 & $6.04902^{*}$ & 1.23373 & 0 & 2.8504 & 9.2477 \\
& 3 & $5.55192^{*}$ & 1.38868 & 0.001 & 1.9516 & 9.1523 \\
\hline
\end{tabular}

*. The mean difference is significant at the 0.05 level.

Table 13: Descriptive statistics, ABC Diffusion and Non-Financial Performance

\begin{tabular}{lrrrr}
\hline & Low & High & Mean & Standard deviation \\
\hline Stage one $(\mathrm{N}=112)$ & 1.67 & 22.50 & 11.41 & 3.795 \\
Stage three $(\mathrm{N}=43)$ & 4.67 & 19.50 & 11.57 & 4.224 \\
Stage five $(\mathrm{N}=20)$ & 3.00 & 19.50 & 12.07 & 4.162 \\
Stage seven $(\mathrm{N}=13)$ & 10.83 & 21.83 & 17.62 & 3.133 \\
\hline
\end{tabular}

Therefore, the results support $\mathrm{H} 2$ which states that firms which are in higher $\mathrm{ABC}$ diffusion stages have a greater level of both financial and non-financial organizational performance.

\section{Discussions}

The accounting literature suggests that firms diffuse a particular accounting system depending on which strategy they adopt. The study does not find support for $\mathrm{H} 1$ which states that prospectors are more likely to be at higher stages of $\mathrm{ABC}$ diffusion. Instead, the results show that analyser strategy, which shares the advantages of both prospector and defender strategies, is the best type of strategy to go to higher $\mathrm{ABC}$ diffusion stages. A number of researchers found evidence that uncertainty in Iran is very high (Samimi and Motameni, 2009). More recently, Charkhide and Tajik, (2012) asserted that there are several instability in Iran due to exchange rate, the inflation, financing sources, interest rate, political, and economical instabilities. A high environmental uncertainty in Iran may explain why the $\mathrm{ABC}$ adoption is rather low among the Iranian manufacturing companies. When an environment is perceived as uncertain, information on customers, suppliers, competitors and economics can be unpredictable or 
difficult to predict. Hence, it is unlikely that companies would consider the adoption of a new system such as $\mathrm{ABC}$ in such condition. Besides, environments that are highly uncertain will tend to generate a lack of confidence on the part of managers. This will likely be viewed as contexts in which erroneous decisions could result in trouble, and will possibly delay decision-making. Under such conditions, the main reason for delaying adopting an innovation is the time needed for innovation adopters to think, to reflect, and to digest ideas.

It seems that in the uncertain environment that the Iranian firms face now, analyzer firms have more tolerance and are able to predict the necessary elements leading to higher $\mathrm{ABC}$ diffusion stages. Thus, the result may cause the analyzer companies to get involved in $\mathrm{ABC}$ as beneficial tool for increasing the value of their cost accounting methods. This significant finding is rather consistent with a study conducted by Bhimani et al. (2005) where they found that strategy influences the decision to experience $\mathrm{ABC}$ and that strategy influences the success of $\mathrm{ABC}$ diffusion. A quite similar finding was also found by Croteau and Bergeron (2001) who revealed that analyzers have a significant impact on technological deployment diffusion.

Hypothesis 2 states that firms which are at higher $\mathrm{ABC}$ diffusion stages have greater levels of firm performance, is fully supported. The results show firms that are in higher $\mathrm{ABC}$ diffusion stages have greater levels of both financial and non-financial financial performance than firms that are in the lower stages. This significant finding is consistent with a study conducted by Kennedy and Affleck-Graves (2001) in which they found that the ABC adoption significantly improves organizational performance, both financial and nonfinancial performance. Evidences from other studies such as Banker et al. (2008), Abernethy and Bouwens (2005), Hughes (2005) also seem consistent with the findings. Furthermore, Cooper et al. (1992) argued that the goal of using $\mathrm{ABC}$ is not only to obtain more accurate costs, but also to increase performance, which is empirically supported by this study.

\section{Implications and Limitations}

The study provides some theoretical and practical implications. From the theoretical perspective, the study contributes to the strategic management and $\mathrm{ABC}$ literatures by providing some evidence concerning the effects of business strategy on $\mathrm{ABC}$ diffusion. In contrast with the existing literature, the findings reveal that, instead of prospector strategy, it is the analyzer strategy that represents the best strategy to go to higher $\mathrm{ABC}$ diffusion stage. The findings add more empirical evidences to the $\mathrm{ABC}$ literature with respect to the relationships between $\mathrm{ABC}$ diffusion stages and firms' financial and non- 
financial performance where firms which are at higher $\mathrm{ABC}$ diffusion stages tend to have greater levels of organizational performance than those in lower $\mathrm{ABC}$ diffusion stages.

From the practical perspective, the findings are vital to the top level managers who are responsible for strategy formulation to decide on the appropriate strategic types. This is because strategy plays a key role in the diffusion process of an innovation such as $\mathrm{ABC}$. Besides, companies tend to place more emphasis on particular accounting techniques depending on which strategy they adopt. The findings also suggest that diffusing the $\mathrm{ABC}$ system improves both financial and non-financial organizational performance. Such findings could be important for non-ABC diffusing firms to consider to diffuse $\mathrm{ABC}$ to improve their organizational performance and achieve their final goal. Companies may be more motivated to adopt $\mathrm{ABC}$ until the infusion stage in order to realize the benefit from the $\mathrm{ABC}$ implementation.

Some limitations of the study are worth to mention as to allow some cautions in interpreting the results. First, a small number of companies that actually adopting $\mathrm{ABC}$ might undermine the reliability of the results. However, this can be acceptable as this study is an exploratory study which intended to lay the groundwork for ABC studies in Iran. Second, this study covers only manufacturing sector companies selected from the Tehran Stock Exchange. Therefore, any generalizations of the results to other sectors (e.g. distribution, retail, services, and transportation) should be treated with caution. In this case, future research should consider other sectors such as the services and non-profit sectors, and government organizations in order to get a better understanding of the $\mathrm{ABC}$ system and its application. Further, a survey approach may reduce some costs and enhance the external validity of the findings, but for further improvement, it would have been better to conduct a mixed-method approach in gathering data such as conducting follow-up interviews and using some secondary data.

\section{Conclusion}

While management accounting literature has shown substantial evidence on $\mathrm{ABC}$ adoption and implementation within the Western context, this study attempted to provide some insight into the $\mathrm{ABC}$ diffusion stages within the Iranian context. The findings suggest that type of business strategy depends on the $\mathrm{ABC}$ diffusion stages while firm performance varies according to the $\mathrm{ABC}$ diffusion stages. The results show that firms tend to follow analyzer strategy and have higher performance when they are at higher stage of $\mathrm{ABC}$ diffusion process. 


\section{References}

Abernethy, M. A., and Bouwens, J. (2005). Determinants of Accounting Innovation Implementation. ABACUS, 41(3), 217-235.

Ahmadzadeh, T., Etemadi, H., and Pifeh, A. (2011). Exploration of Factors Influencing on Choice the Activity-Based Costing System in Iranian Organizations. International Journal of Business Administration, 2(1), 6170.

Al-Omiri, M., and Drury, C. (2007). Organizational and behavioral factors influencing the adoption and success of abc in the UK. Cost Management. Boston, 21(6), 38-49.

Anderson, S. W. (1995). A Framework for Assessing Cost Management System Changes: The Case of Activity Based Costing Implementation at General Motors, 1986-1993. Journal of Management Accounting Research, 7, 1-51.

Askarany, D., Smith, M., and Yazdifar, H.. (2007). Technological Innovations, Activity Based Costing And Satisfaction. Journal of Accounting - Business and Management, 14, 53-63.

Askarany, D., and Yazdifar, H. (2012). An investigation into the mixed reported adoption rates for $\mathrm{ABC}$ : Evidence from Australia, New Zealand and the UK. International Journal of Production Economics, 135(1), 430-439.

Banker, R. D., Bardhan, I. R., and Chen, T. Y. (2008). The role of manufacturing practices in mediating the impact of activity-based costing on plant performance. Accounting, Organizations and Society, 33, 1-19.

Bhimani, A. and Gosselin, M. and Ncube, M. (2005). Strategy and activity based costing: a cross national study of process and outcome contingencies. International Journal of Accounting, Auditing and Performance Evaluation, 2 (3), 187-205

Bjørnenak, T. (1997). Diffusion and accounting: the case of ABC in Norway. Management Accounting Research, 8(1), 3-17.

Brown, D. A., Booth, P. and Giacobbe, F. (2004). Technological and organizational influences on the adoption of activity-based costing in Australia. Accounting and Finance, 44, 329-356.

Cagwin, D. and Bouwman, M. J. (2002). The association between activity-based costing and improvement in financial performance. Management Accounting Research, 13, 1-3.

Charkhide, A. and Tajik, M. (2012). The role and importance of economic security in ensuring sustainable development. Chamber of Iranian Commerce Publication, 59, 13-16. 
Clarke, P. J., Hill, N. T. and Stevens, K., (1999). Activity-Based Costing in Ireland: Barriers to, and Opportunities for change. Critical Perspectives on Accounting, 10, 443-468.

Clarke, P. and Mullins, T. (2001). Activity based costing in the nonmanufacturing sector in Ireland: A preliminary investigation. Irish Journal of Management. Dublin, 22(2), 1-19.

Cohen, S., Venieris, G. and Kaimenaki, E., (2005). ABC: adopters, supporters, deniers and unawares. Managerial Auditing Journal, 20(8/9), 981-1000.

Cooper, R., and Kaplan, R. S. (1991). Profit Priorities from Activity-Based Costing. Harvard Business Review, 69(3), 130-136.

Cooper, R., Kaplan, R. S., Maisel, L. S. and Morrissey, E. O. (1992). From ABC to ABM. Management Accounting. 74(5), 54-57.

Cooper, R. B., and Robert W. Zmud. (1990). Information Technology Implementation Research: A Technological Diffusion Approach Management Science, 36(3).

Croteau, A. M. and Bergeron, F. (2001). An information technology trilogy: business strategy, technological deployment and organizational performance. Journal of Strategic Information Systems, 10, 77-99.

Damanpour, F. (1987). The Adoption of Technological, Administrative, and Ancillary Innovations: Impact of Organization Factors. Journal of Management, 13(4), 675-688.

Drury, Colin and Tayles, M. (2005). Explicating the design of overhead absorption procedures in UK organisations. British Accounting Review, 37 (1), 47-84.

Elhamma, A. and Yi Fei, Z. (2013). The relationship between activity-based costing, business strategy and performance in Moroccan enterprises, Accounting and Management Information Systems, 12(1), 2238.

Galbreath, J. (2009). Building corporate social responsibility into strategy. European Business Review, 21,109-127.

Gering, M. (1999). Activity based costing and performance improvement", Management Accounting, 73, 24-27.

Gosselin, M. (1997). The Effect of Strategy and Organizational Structure on the Adoption and Implementation Activity-Based Costing. Accounting, Organizations and Society, 22(2), 105-122.

Govindarajan, V. J. and Gupta, A. K. (1985). Linking control systems to business unit strategy: Impact on performance. Accounting, Organizations and Society, 10, 51-66. 
Hughes, A. (2005). ABC/ABM - activity-based costing and activity-based management: A profitability model for SMEs manufacturing clothing and textiles in the UK. Journal of Fashion Marketing and Management, 9(1), 819.

Innes, J. and Mitchell, F. (1995) A survey of activity-based costing in the U.K. 's largest companies. Management Accounting Research, 6, 137-152.

Innes, J., Mitchell, F. and Sinclair, D. (2000). Activity-based costing in the U.K.'s largest companies: a comparison of 1994 and 1999 survey results. Management Accounting Research, 11, 349-362.

Johnson, H. T. and Kaplan, R. S. (1987). Relevance Lost: The Rise and Fall of Management Accounting. Harvard Business School Press: Boston, MA.

Jusoh, R., Ibrahim, D. N. and Zainuddin, Y. (2006). Assessing the Alignment Between Business Strategy and Use of Multiple Performance Measures Using Interaction Approach. The Business Review, Cambridge, 5(1), 51-61.

Jusoh, R. and Parnell, J. A. (2008). Competitive strategy and performance measurement in the Malaysian context An exploratory study. Management Decision, 46(1), 5-31.

Kennedy, T. and Affleck-Graves, J. (2001). The impact of activity-based costing techniques on firm performance. Journal of Management Accounting Research, 13(1), 19-45.

Khalid, A. (2005). Activity-Based Costing in Saudi Arabia's Largest 100 Firms in 2003. Journal of American Academy of Business, 6(2), 285-292.

Kiani, R. and Sangeladji, M. (2003). An empirical study about the use of the $\mathrm{ABC} / \mathrm{ABM}$ models by some of the Fortune 500 largest industrial corporations in the USA. Journal of American Academy of Business, 3(1/2), 174-182.

Krumwiede, K. R. (1998). The Implementation Stages of Activity-Based Costing and the Impact of Contextual and Organizational Factors. Journal of Management Accounting Research, 10, 239-277.

Krumwiede, K. R. and Roth, H. P. (1997). Implementing information technology innovations: The activity-based costing example. Advanced Management Journal, 62(4), 4-14.

Krumwiede, K. R. and Suessmair, A. (2005). Factors affecting the adoption, infusion, and perceived success of German cost accounting methods. Paper presented at the AAA Management Accounting Section Meeting.

Maelah, R., and Ibrahim, D. N. (2007). Factors influencing activity based costing $(\mathrm{ABC})$ adoption in manufacturing industry. Investment Management and Financial Innovations. Sumy: 2007. Vol. 4, Iss. 2; pg. 113, 13 pgs, 4(2), 113-127. 
Mia, L. and Clarke, B. (1999). Market competition, management accounting systems and business unit performance. Management Accounting Research, 10, 137-1 58 .

Miles, R. E. and Snow, C. C. (1978). Organizational Strategy, Structure, and Process, McGraw - Hill.

Moll, S. (2005). Activity Based Costing in New Zealand. Dissertation, University of Otago, Dunedin.

Porter, M. E. (1987). From Competitive Advantage to Coporate Strategy. Harvard Business Review, 65(3), 43-60.

Ríos-Manríquez, M., Muñoz Colomina, C.I., and Rodríguez-Vilariño Pastor, M.L. (2014). Is the activity based costing system a viable instrument for small and medium enterprises? The case of Mexico, Estudios Gerenciales, 30(132), 220-232.

Rogers, E. M. (2003). Diffusion of Innovation: Free Press.

Samimi, A. J. and Motameni, M. (2009). Inflation and Inflation Uncertainty in Iran. Australian Journal of Basic and Applied Sciences 3(3), 2935-2938.

Sekaran, U., Cavana, R. Y. and Delahaye, B. L. (2000). Applied Business Research: Qualitative and Quantitative Methods: John Wiley and Sons Australia, Ltd.

Shields, M. D. and McEwen, M. A. (1996). Implementing activity-based costing systems successfully. Journal of Cost Management, 9 (4), 15-22. 


\section{Appendix 1: Survey Questions for Business Strategy}

The following questions relate to the business strategy your organization is pursuing. Each of these twelve questions containing four statements where each statement represents a particular strategy pursued. Please indicate to what extend you agree or disagree with each of the statement using the five-point below. Please circle only one of the numbers.

\begin{tabular}{|c|c|c|c|c|c|}
\hline $\begin{array}{l}\text { The level of agreement } \\
\text { Statements }\end{array}$ & $\begin{array}{l}\text { Strongly } \\
\text { Disagree }\end{array}$ & Disagree & $\begin{array}{l}\text { Some } \\
\text { what } \\
\text { Agree }\end{array}$ & Agree & $\begin{array}{l}\text { Strongly } \\
\text { Agree }\end{array}$ \\
\hline $\begin{array}{l}\text { Considering our products, we } \\
\text { F1) primarily seek to provide our products at } \\
\text { the lowest possible price; } \\
\text { F2) Primarily seek to differentiate our products } \\
\text { from those of our competitors; } \\
\text { F3) Tend to emphasize one or more factors } \\
\text { such as quality, price or uniqueness for a } \\
\text { while, and later emphasize other factors; } \\
\text { F4) Primarily seek to provide products most } \\
\text { consistent with consumer demands; }\end{array}$ & $\begin{array}{l}1 \\
1 \\
1\end{array}$ & $\begin{array}{l}2 \\
2 \\
2\end{array}$ & $\begin{array}{l}3 \\
3 \\
3 \\
3\end{array}$ & $\begin{array}{l}4 \\
4 \\
4\end{array}$ & $\begin{array}{l}5 \\
5 \\
5 \\
5\end{array}$ \\
\hline $\begin{array}{l}\text { In the future we plan to position our company } \\
\text { in the marketplace as: } \\
\text { F5) One that does the best job meeting } \\
\text { consumers demands; } \\
\text { F6) One that does whatever that generates the } \\
\text { greater return at that time; } \\
\text { F7) One that satisfies the demands of a } \\
\text { particular group of consumers exceptionally } \\
\text { well; } \\
\text { F8) One that leads the way in new products; }\end{array}$ & $\begin{array}{l}1 \\
1\end{array}$ & $\begin{array}{l}2 \\
2\end{array}$ & $\begin{array}{l}3 \\
3\end{array}$ & 4 & $\begin{array}{l}5 \\
5\end{array}$ \\
\hline $\begin{array}{l}\text { If asked about our company, most current and } \\
\text { prospective customers would: } \\
\text { F9) Consider us to be an efficient producer of } \\
\text { goods; } \\
\text { F10) Consider us to be highly innovative; } \\
\text { F11) Feel as if we understand them well as } \\
\text { consumers; } \\
\text { F12) Identify us with no particular area of } \\
\text { distinctive competence; }\end{array}$ & $\begin{array}{l}1 \\
1 \\
1 \\
1\end{array}$ & $\begin{array}{l}2 \\
2 \\
2 \\
2\end{array}$ & $\begin{array}{l}3 \\
3 \\
3 \\
3\end{array}$ & $\begin{array}{l}4 \\
4 \\
4 \\
4\end{array}$ & $\begin{array}{l}5 \\
5 \\
5 \\
5\end{array}$ \\
\hline $\begin{array}{l}\text { How does your company view change in the } \\
\text { marketplace or your external environment? } \\
\text { F13) We usually try to initiate change; } \\
\text { F14) We do not think much about change; } \\
\text { F15) We usually try to adopt to change; } \\
\text { F16) We usually try to resist change; }\end{array}$ & $\begin{array}{l}1 \\
1 \\
1 \\
1\end{array}$ & $\begin{array}{l}2 \\
2 \\
2 \\
2\end{array}$ & $\begin{array}{l}3 \\
3 \\
3 \\
3\end{array}$ & $\begin{array}{l}4 \\
4 \\
4 \\
4\end{array}$ & $\begin{array}{l}5 \\
5 \\
5 \\
5\end{array}$ \\
\hline $\begin{array}{l}\text { Most current and prospective costumers } \\
\text { probably: } \\
\text { F17) See our products as among the lowest } \\
\text { priced available; } \\
\text { F18) See our products to be the most in-tune } \\
\text { with customer demands; } \\
\text { F19) Consider our products among the most } \\
\text { unique; } \\
\text { F20) See different attributes in our products; }\end{array}$ & $\begin{array}{l}1 \\
1 \\
1 \\
1\end{array}$ & $\begin{array}{l}2 \\
2 \\
2 \\
2\end{array}$ & $\begin{array}{l}3 \\
3 \\
3 \\
3\end{array}$ & $\begin{array}{l}4 \\
4 \\
4 \\
3\end{array}$ & $\begin{array}{l}5 \\
5 \\
5 \\
5\end{array}$ \\
\hline
\end{tabular}




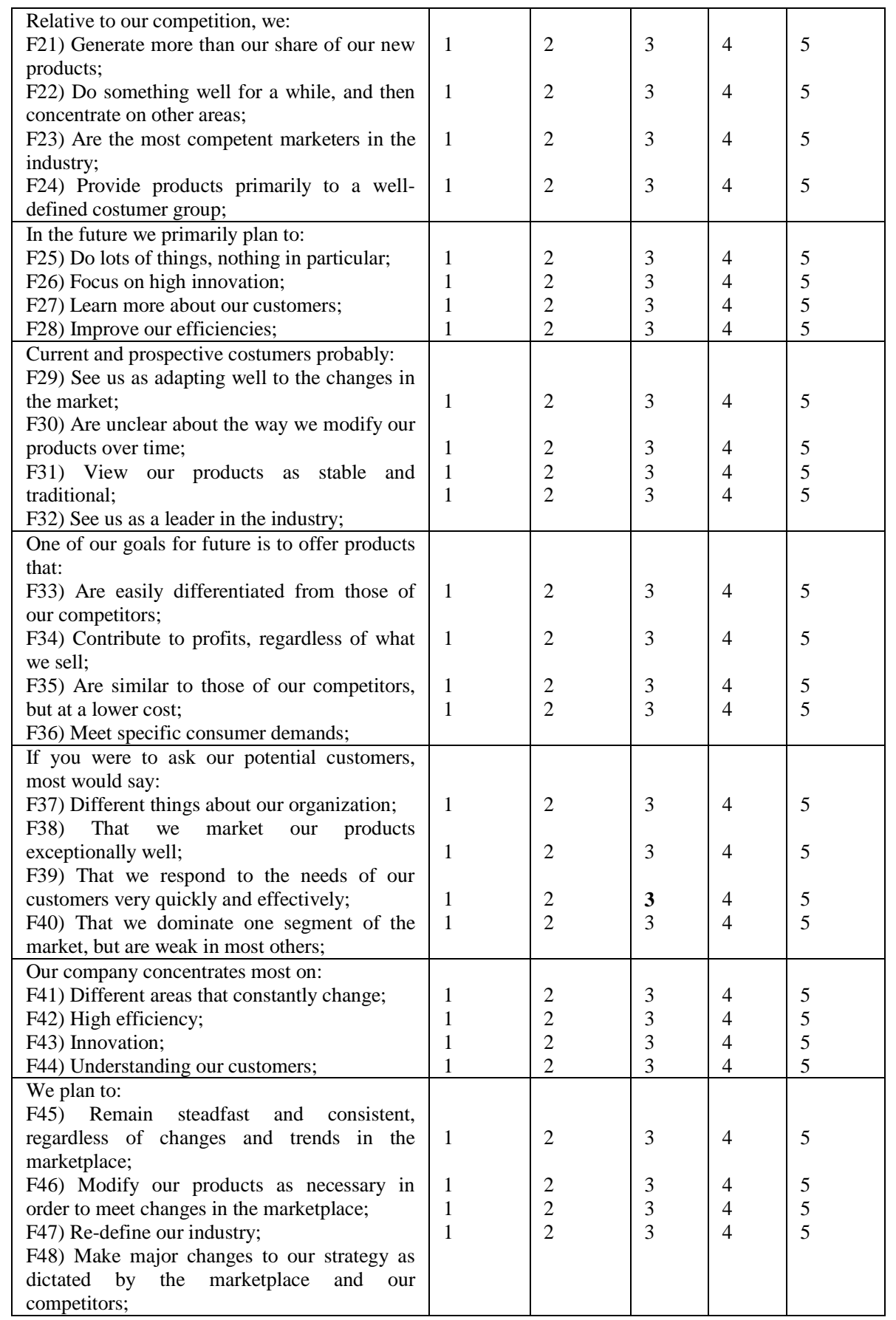




\section{Appendix 2: Survey Questions for ABC Diffusion}

$\mathrm{K}$. Regarding activity or process based costing $(\mathrm{ABC})$; please put $\mathrm{X}$ in the ONE of the following stages that best describe your company current situation:

K1) Not considered:

$\mathrm{ABC}$ has not been seriously considered. We use either single or departmental/multiple plantwide allocation methods only.

K2) Evaluated then rejected:

$\mathrm{ABC}$ has been evaluated (but not implemented) and was later rejected as a cost assignment/ management method.

K3) Initiation/evaluating:

$\mathrm{ABC}$ is being evaluated and implementation is possible, but implementation has not yet been approved.

K4) Implemented then abandoned:

$\mathrm{ABC}$ was previously implemented but is not currently being used.

K5) Used occasionally:

Occasionally used by non-accounting management or departments for decision making.

K6) Used frequently:

Frequently used for management decision making; considered normal part of information system.

K7) Used extensively:

Used extensively for management decision making; clear benefits of $\mathrm{ABC}$ can be identified.

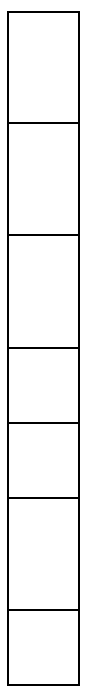

\section{Appendix 3: Survey Questions for Organizational Performance}

J1. How important does your companies rate the following measures of performance? Please indicate by circling the most appropriate level of importance below:

\begin{tabular}{|l|c|c|c|c|c|}
\hline \multicolumn{1}{|c|}{ The level of Importance } & $\begin{array}{l}\text { Not } \\
\text { important }\end{array}$ & $\begin{array}{l}\text { Little } \\
\text { important }\end{array}$ & $\begin{array}{l}\text { Medium } \\
\text { important }\end{array}$ & $\begin{array}{l}\text { Very } \\
\text { Important }\end{array}$ & $\begin{array}{l}\text { Critically } \\
\text { important }\end{array}$ \\
\hline J1-1) Sales volume & 1 & 2 & 3 & 4 & 5 \\
\hline J1-2) On time delivery & 1 & 2 & 3 & 4 & 5 \\
\hline J1-3) Cash flow & 1 & 2 & 3 & 4 & 5 \\
\hline J1-4) Competitor monitoring & 1 & 2 & 3 & 4 & 5 \\
\hline J1-5) Market share & 1 & 2 & 3 & 4 & 5 \\
\hline J1-6) Return on investment & 1 & 2 & 3 & 4 & 5 \\
\hline J1-7) New product introduction & 1 & 2 & 3 & 4 & 5 \\
\hline J1-8) Time to process activities & 1 & 2 & 3 & 4 & 5 \\
\hline J1-9) Customer satisfaction & 1 & 2 & 3 & 4 & 5 \\
\hline J1-10) Productivity of labour & 1 & 2 & 3 & 4 & 5 \\
\hline J1-11) Profile with the community & 1 & 2 & 3 & 4 & 5 \\
\hline J1-12) Cost reduction & 1 & 2 & 3 & 4 & 5 \\
\hline J1-13) Cost & 1 & 2 & 3 & 4 & 5 \\
\hline J1-14) Customer monitoring & 1 & 2 & 3 & 4 & 5 \\
\hline J1-15) Employee safety & 1 & 2 & 3 & 4 & 5 \\
\hline J1-16) Products quality & 1 & 2 & 3 & 4 & 5 \\
\hline
\end{tabular}


J2. How well do you believe your organization has currently performed compared to your competitors with respect to the following performance indicators?

\begin{tabular}{|l|l|l|l|l|c|}
\hline \multicolumn{1}{|c|}{ The level of Performance } & $\begin{array}{l}\text { Strongly } \\
\text { Below } \\
\text { Indicators } \\
\text { Average }\end{array}$ & $\begin{array}{l}\text { Below } \\
\text { the } \\
\text { Average }\end{array}$ & Average & $\begin{array}{l}\text { Above } \\
\text { Average }\end{array}$ & $\begin{array}{l}\text { Strongly } \\
\text { Above } \\
\text { Average }\end{array}$ \\
\hline J2-1) Sales volume & 1 & 2 & 3 & 4 & 5 \\
\hline J2-2) On time delivery & 1 & 2 & 3 & 4 & 5 \\
\hline J2-3) Cash flow & 1 & 2 & 3 & 4 & 5 \\
\hline J2-4) Competitor monitoring & 1 & 2 & 3 & 4 & 5 \\
\hline J2-5) Market share & 1 & 2 & 3 & 4 & 5 \\
\hline J2-6) Return on investment & 1 & 2 & 3 & 4 & 5 \\
\hline J2-7) New product introduction & 1 & 2 & 3 & 4 & 5 \\
\hline J2-8) Time to process activities & 1 & 2 & 3 & 4 & 5 \\
\hline J2-9) Customer satisfaction & 1 & 2 & 3 & 4 & 5 \\
\hline J2-10) Productivity of labour & 1 & 2 & 3 & 4 & 5 \\
\hline J2-11) Profile with the community & 1 & 2 & 3 & 4 & 5 \\
\hline J2-12) Cost reduction & 1 & 2 & 3 & 4 & 5 \\
\hline J2-13) Cost & 1 & 2 & 3 & 4 & 5 \\
\hline J2-14) Customer monitoring & 1 & 2 & 3 & 4 & 5 \\
\hline J2-15) Employee safety & 1 & 2 & 3 & 4 & 5 \\
\hline J2-16) Products quality & & & & \\
\hline
\end{tabular}

